U.S. Department of Energy

Portsmouth

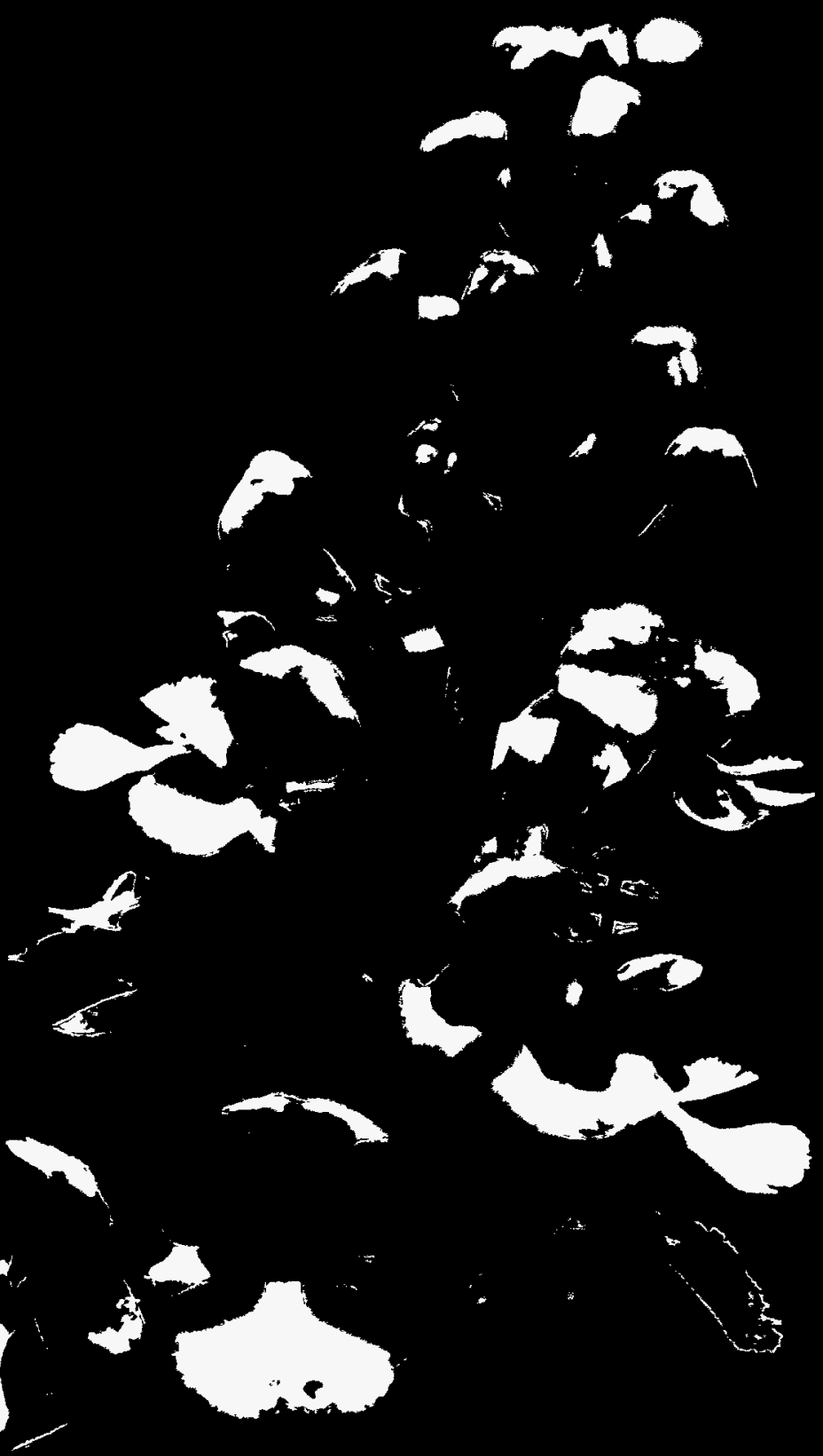

Site

\author{
Annual
}

Environmental

Report Summary for 1994 
This report has been reproduced directly from the best available copy.

Available to DOE and DOE contractors from the Office of Scientific and Technical Information, P.O. Box 62, Oak Ridge, TN 37831; prices available from (615) 576-8401.

Available to the public from the National Technical Information Service, U.S. Department of Commerce, 5285 Port Royal Rd., Springfield, VA 22161.

This report was prepared as an account of work sponsored by an agency of the United States Government. Neither the United States nor any agency thereof, nor any of their employees, makes any warranty, express or implied, or assumes any legal liability or responsibility for the accuracy, completeness, or usefulness of any information, apparatus, product, or process disclosed, or represents that its use would not infringe privately owned rights. Reference herein to any specific commercial product, process, or service by trade name, trademark, manufacturer, or otherwise, does not necessarily constitute or imply its endorsement,

On the cover: The purple fringeless orchid (Platanthera peramoena) is found on the DOE reservation. (ORNL PHOTO 7546-90)

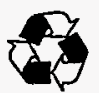


ES/ESH-64

POEF-3057

\section{U.S. Department of Energy Portsmouth Site Annual Environmental Report Summary for 1994}

Project director

D. W. Frazier

Project coordinator

D. C. West

Technical coordinator

S. C. Newman/P. A. Sperling

Coordinating editor

C. M. Horak

Published: March 1996

Prepared by Environmental, Safety, and Health Compliance and Environmental Management staffs, Lockheed Martin Energy Systems, Inc., P.O. Box 2008, Oak Ridge, Tennessee 37831-6285, and the Environmental Management Division, Portsmouth Site, Lockheed Martin Energy Systems, Inc., P.O. Box 628, Piketon, Ohio 45661, for the U.S. Department of Energy, under contract No. DE-AC05-84OR21400. 


\section{PREFACE}

This pamphlet contains summaries of the environmental programs at the Portsmouth site, including environmental monitoring and results and the impact of plant operations on the environment and the public for 1994. More detailed information on the material summarized in this pamphlet is available in the Portsmouth Site Annual Environmental Report for 1994. The data used to compile the site annual environmental report and this summary pamphlet are published in the Portsmouth Site Annual Environmental Data for 1994, which is a collection of tables containing effluent monitoring, environmental surveillance, and dose calculation data for 1994.

To obtain copies of any of these documents, contact

Environmental Management

P.O. Box 628

Building X7725, MS-7556

Portsmouth Gaseous Diffusion Plant

Piketon, $\mathrm{OH} 45661$

Telephone: 614-897-3603 


\section{ABOUT THE PORTSMOUTH SITE}

The Portsmouth plant is one of two U.S. Department of Energy (DOE)-owned, contractor-managed uranium enrichment facilities (see Figure 1). As of July 1, 1993, responsibility for implementing environmental compliance at the facility was split between $\mathrm{DOE}$, as site owner and operator of waste management and environmental remediation projects, and the United States Enrichment Corporation (USEC), a government-owned corporation formed by the Energy Policy Act of 1992 to take over the nation's uranium enrichment business. The management contractor for DOE is Lockheed Martin Energy Systems (formerly Martin Marietta Energy Systems). Lockheed Martin Utility Services (formerly Martin Marietta Utility Services) provides management services for USEC. The Nuclear Regulatory Commission is scheduled to assume direct oversight of USEC operations by the end of 1996 . Until then, DOE is providing oversight of nuclear safety and safeguards and security.

The Portsmouth facility is located on about 6 square miles in Pike County, Ohio (Figure 2). The County has approximately 24,250 residents. The total population within 50 miles of the plant is about 900,000 . Figure 3 shows the plant site and its immediate surroundings.

The main process at the Portsmouth facility has been the separation of uranium isotopes through gaseous diffusion. DOE no longer enriches uranium at the Portsmouth site. The uranium enrichment production operation facilities at the site are leased to USEC.

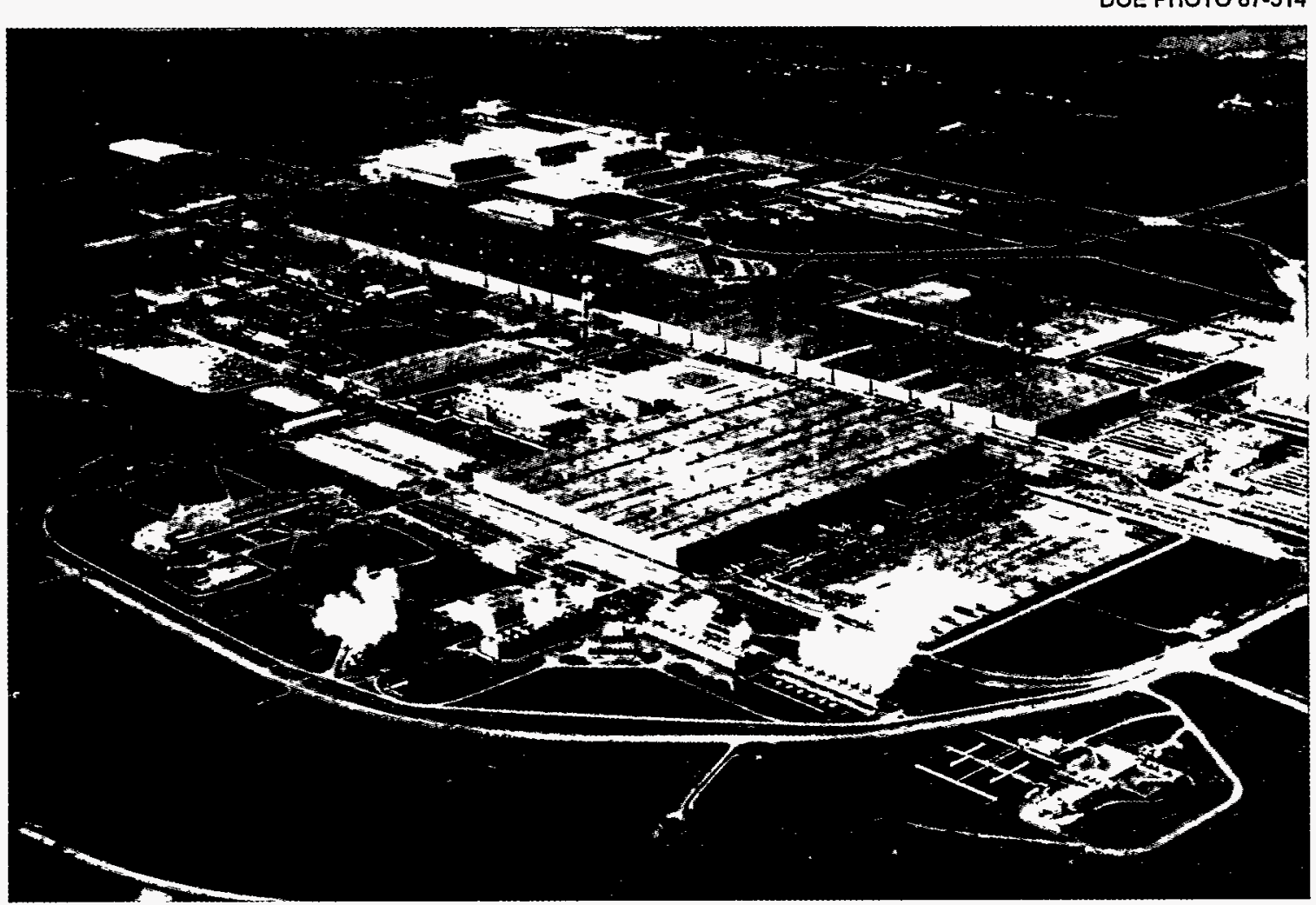

Figure 1. The Portsmouth plant is one of two U.S. government-owned, contractor-operated uranium enrichment facilities. The other facility is Paducah, Kentucky. 
ORNL-DWG 87M-6713R

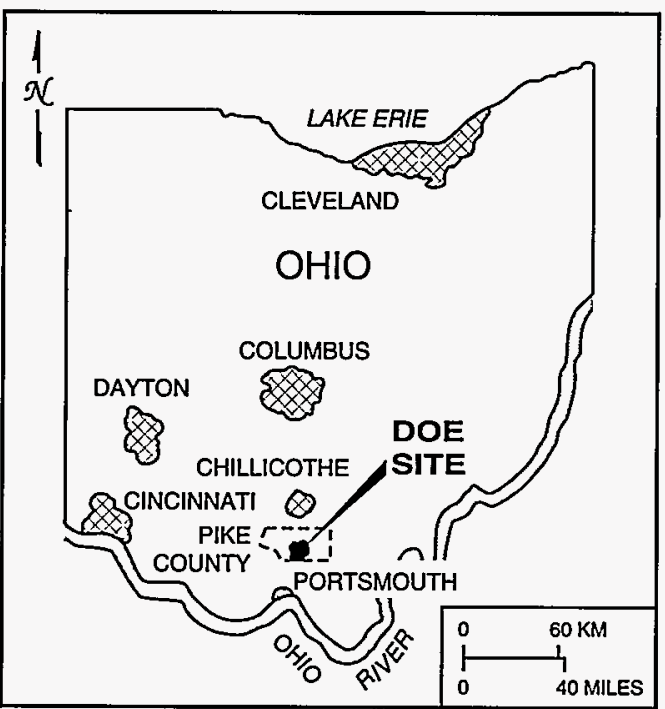

Figure 2. Location of the Portsmouth site within the state of Ohio.

\section{STATE AND FEDERAL LAWS AND REGULATIONS}

The philosophy of environmental compliance at the Portsmouth site is to protect employee and public health and the environment while complying fully with all environmental rules and regulations. Growth in public awareness and environmental concern in recent years has prompted Congress to pass increasingly stringent laws to protect the environment. In keeping with our philosophy, we continue to work closely with the regulating agencies to minimize the effect of plant activities on public health and the environment and to ensure continued compliance with regulations.

The U.S. Environmental Protection Agency (USEPA) and the Ohio

Environmental Protection Agency are the principal regulatory agencies. These agencies issue permits, review compliance reports, participate in joint monitoring programs, inspect facilities and operations, and oversee compliance with applicable regulations. To continue operations, Portsmouth facilities must comply with numerous federal and state laws, a few of which follow.

- Clean Air Act

- Clean Water Act

- Comprehensive Environmental Response, Compensation, and Liability Act

- Emergency Planning and Community Right-To-Know Act

- Endangered Species Act

- Farmland Protection Act

- Federal Facilities Compliance Act

- Federal Insecticide, Fungicide, and Rodenticide Act

- National Environmental Policy Act

- National Historic Preservation Act 
- Resource Conservation and Recovery Act

- Safe Drinking Water Act

- Toxic Substances Control Act

\section{COMMUNITY PARTICIPATION}

A comprehensive community relations and public participation program on the Environmental Restoration and Waste Management Program has been established since early 1990 . The purpose of the program is to conduct a proactive public involvement program, with outreach components, to foster a spirit of openness and credibility among local citizens and various segments of the public. The program is also geared to provide the public with opportunities to become involved in decisions affecting environmental issues at the site.

DOE opened a public Environmental Information Center in February 1993 in an effort to provide public access to all documents used to drive decisions on remedial actions being taken at the plant. The information center has a full-time staff and is located about 10 miles north of the plant at 505 West Emmitt Avenue, Suite 3, Waverly, Ohio 45690. The center's hours are 10 a.m. to 4 p.m., Monday, Tuesday, Wednesday, and Friday, and 9 a.m. to 12 p.m. on Thursday, or after hours by appointment (614-947-5093).

A group of about 45 key stakeholders, composed of elected officials, community leaders, environmentalists, and other individuals who have expressed an interest in the Environmental Restoration and Waste Management Program, is targeted for information and input on current activities and those actions under consideration at the plant site. Semiannual public update meetings are also held, as well as public workshops on specific topics to keep the public informed and to receive their comments and questions.

Periodically, fact sheets about major projects are written for the public, and semiannual newsletters are printed and distributed to more than 4000 recipients, including the community relations mailing list, neighbors within two-miles of the plant site, and all plant site employees and retirees.

Points of contact have been established for the public to obtain information or direct questions regarding the Environmental Restoration and Waste Management Program. The deputy site manager for DOE is the primary point of contact at 614-897-5510. The Lockheed Martin Energy Systems site manager and the Public Affairs manager also provide information on the program.

\section{RESTORING THE ENVIRONMENT AND MANAGING WASTE}

Environmental restoration and waste management activities are carried out to protect the local population, improve the quality of the environment, and comply with federal and state regulations.

- Environmental restoration is the cleanup of wastes in the environment that originated from activities on the reservation.

-Waste management is the control of wastes, including their destruction or permanent storage.

\section{Environmental Restoration}

Environmental restoration is the process of cleaning up inactive waste sites and facilities to ensure that risks to human health and the environment are either eliminated or 
reduced to safe levels. DOE established the Environmental Restoration Program to find, analyze, and correct site contamination problems as quickly and inexpensively as possible. This task may be accomplished by removing, stabilizing, or treating hazardous substances. The federal law that addresses the restoration of inactive waste sites is the Resource Conservation and Recovery Act (or RCRA). This legislation includes identification of waste sites with the need for cleanup because of increased risk to public health or the environment. The Portsmouth site Environmental Restoration Program was developed in 1989 and was granted an initial budget of 13.8 million dollars. Since then, annual program expenditures have grown to 50 to 60 million dollars.

\section{Waste Management}

The Portsmouth site Waste Management Program directs the safe storage, treatment, and disposal of waste generated from operations and from environmental restoration projects. The main goal is to ensure that waste materials do not migrate into the environment.

Waste management requirements are varied and often complex because of the variety of wastes generated by Portsmouth facility activities. DOE orders and OEPA, USEPA, and Ohio Department of Health regulations must be satisfied to ensure compliance of waste management activities. Supplemental policies have been implemented for management of radioactive, hazardous (chemical), and mixed (radioactive and hazardous) wastes. These policies include

- minimizing wastes;

- characterizing and certifying wastes before they are stored, processed, treated, or disposed of; and

- pursuing volume reduction and use of on-site storage when safe and cost effective until a final disposal option is identified.

\section{WE MONITOR THE ENVIRONMENT}

The environmental monitoring program at the Portsmouth site has two components-effluent monitoring and environmental surveillance, both of which are intended to demonstrate that plant operations comply with DOE criteria as well as other applicable federal, state, and local standards and requirements.

- Effluent monitoring is sampling known air and water discharge points to determine the amount of radioactive and chemical contaminants (if any) contained in the released material. These releases occur as part of normal site operations, such as cooling water discharged from the uranium enrichment cascade operations or airborne releases from ventilation systems.

- Environmental surveillance is sampling air and water to detect any radioactive or chemical contaminants that could have come from site activities.

Information from monitoring and surveillance is then used to document compliance with appropriate standards, identify trends, inform the public, and contribute to general environmental knowledge. 
We monitor the local environment to acquire data so that we can reduce and, where practical, eliminate the release of radioactive and nonradioactive hazardous materials. Information gathered during specific monitoring programs is published in routine reports to local, state, and federal agencies and to the public. The environmental monitoring program assists in fulfilling DOE's policy of protecting the public, employees, and the environment from harm that could be caused by its activities and in reducing negative environmental impacts to the greatest degree practical.

\section{QUALITY ASSURANCE AND QUALITY CONTROL}

When monitoring releases and measuring radiation in the environment, the reliability of the data is of the utmost importance. To ensure that the monitoring and measurement results are accurate, the Portsmouth site has a quality assurance and quality control program that is based on guidelines from the USEPA, the American Society for Testing and Materials, and other federal and state agencies. Portsmouth staff administer numerous quality control programs to ensure reliability of the data on a day-to-day basis. The Portsmouth site also participates actively in quality control programs administered by agencies outside the site, such as the USEPA and the National Institute of Occupational Safety and Health. These agencies prepare and distribute test samples for participating laboratories to analyze. The agencies then compile and evaluate the results and report to each laboratory on the accuracy of that laboratory's analyses. In 1994, the Portsmouth site laboratory performed over 2000 external control measurements, with $97.7 \%$ of the results being acceptable.

\section{WE STUDY THE EFFECTS OF RADIATION AND CHEMICALS}

Activities at the Portsmouth site involve handling radioactive materials, operating radiation-producing equipment, and working with chemicals known to be harmful to humans and the environment. Radiological and chemical "dose" assessments evaluate the possible exposure of the public to radioactive elements and harmful chemicals as a result of routine operations at the site. We assess and record compliance with regulations for protection of employees, the public, and the environment.

The most important potential source of exposure to radiation from

\section{How are Workers and the Public Being Protected?}

Each process operations building at the Portsmouth site is equipped with alarms that automatically warn employees of significant increases in radiation levels. Dosimeters, or radiation-sensitive personnel badges, are worn by all employees and visitors entering any plant-site limited area. Protective clothing and respiratory equipment are worn during work assignments involving an increased risk of contacting radioactive materials, and workers are monitored for contamination when leaving restricted areas. Employees undergo extensive training so that they understand operating procedures and all emergency and safety requirements.

A public warning system has also been in place at the site since 1988 . In the unlikely event of a significant environmental release with the potential to go off site, the public warning sirens would be activated to notify all residents within a 2-mile radius of the site. Local emergency preparedness agencies and area media would also be notified simultaneously. 
the Portsmouth site is from airborne releases of uranium and technetium; the most important potential source of exposure to harmful chemicals is from airborne gaseous fluorides.

Thousands of samples of air, soil, and water are analyzed each year. The results are used to determine the amount of exposure that a hypothetical, "maximally exposed" individual could receive in a year as a result of plant operations.

\section{WHAT DO WE MEAN BY RISK?}

When we estimate the risk associated with activities at the Portsmouth site, we are calculating the odds of site activities affecting the health of the local population. These calculations are based on known effects that chemicals and radiation have on the human body. All of the sampling and analysis compiled in the Portsmouth site annual environmental report culminate in the calculation of "dose" of radiation and chemicals to the public (if any) that can be attributed to the activities at the site.

The calculated maximum effective dose equivalent for radiation in 1994 was $0.066 \mathrm{mrem}$. This calculation is based on a hypothetical adult who would have received the maximum exposure from all reservation sources during the year. This amount is a small fraction of the natural local background, which averages 300 mrem per year (see Figure 4).

When calculating maximum doses from releases to the air and water from Portsmouth site operations, the concept of a hypothetical individual who receives the maximum exposure from all pathways is used. This maximally exposed individual:

- for air pathways, lives at the most exposed point on the Portsmouth boundary 365 days a year and consumes milk, meat, and vegetables produced within 50 miles of the site; and

- for liquid pathways, drinks 190 gallons of untreated river water, eats 46 pounds of fish caught in the Scioto River, swims for 27 hours in the river, boats for 105 hours on the river, and occupies the shoreline for 69 hours during the year.

Portsmouth uses the concept of the maximally exposed individual when estimating its contribution to the dose to the off-site population to ensure that the estimate is the highest any one individual could have received as a result of site operations. In reality, however, no individual actually receives a dose of this magnitude from Portsmouth site operations.

Figure 4. Comparison of combined dose from all exposure pathways from Portsmouth site operations to background dose and DOE limit. Portsmouth's contribution to the dose of 0.066 mrem was $0.07 \%$ of the 100 -mrem DOE limit and $0.02 \%$ of the 300 -mrem background radiation.

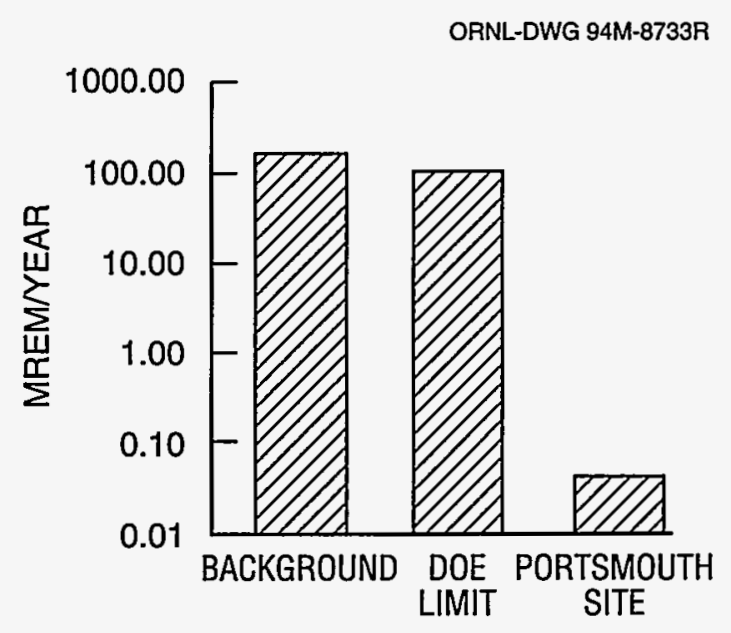




\section{RADIATION}

Radioactive material contains unstable atoms (isotopes) that become stable by emitting electromagnetic radiation and high-energy particles. All naturally occurring and human-made isotopes are unique with regard to the particles and energy they emit.

- Dose is an estimate of the amount of radiation that a body has received (in units of rads or grays).

- Dose equivalent is an estimate of damage to a specific organ based on the radiation it has absorbed (in units of rem or sieverts).

- Effective dose equivalent relates the dose equivalents to the risk to the whole body.

\section{CHEMICALS}

- Chemical dose is the estimate of the amount of a chemical to which a human body is exposed daily.

- Toxicity refers to the adverse effects, ranging from mild irritation to death, that a chemical can have on human health. Dose estimates are compared with USEPA standards to benchmark their level of toxicity.

- Carcinogens are a class of toxic chemicals that are known cancer-causing agents.

\section{CHEMICAL AND RADIOLOGICAL CONTAMINANT PATHWAYS}

We can receive internal or external exposure to chemicals and radioactive materials by way of a number of pathways: direct, airborne, waterborne, and the food chain. We receive radiation directly from cosmic radiation and from particles embedded in soil and suspended in air and water. We can breathe air and drink water that have both chemical and radiological airborne contaminants suspended in them. Similarly, airborne contaminants that settle on grass in a pasture can be eaten by cows, and the contaminants could show up in the milk we drink. Similarly, contaminants in water can be ingested and retained by fish that we eat (see Figure 5).

At the Portsmouth facility, essentially all of the radiation dose to the public is from the elements uranium and technetium. Of the two, 1 curie of uranium will cause committed dose equivalents 100 times greater than 1 curie of technetium if swallowed, and 1000 times greater if inhaled. Consequently, the Portsmouth site has always considered controlling uranium emissions to be far more important than controlling technetium emissions.

\section{WE MONITOR DIRECT RADIATION}

The annual effective-dose-equivalent rate for the state of Ohio averages $115 \mathrm{mrem}$ per year. The average for the United States as a whole is slightly lower, a little over 100 mrem per year. To determine whether radioactive releases from the Portsmouth site are significantly increasing radiation levels above the normal background levels, direct radiation exposure rates are measured at locations on and off the plant site and are converted to dose equivalent units (millirems). To estimate the maximum dose that could 
ORNL-DWG 94M-5235R2

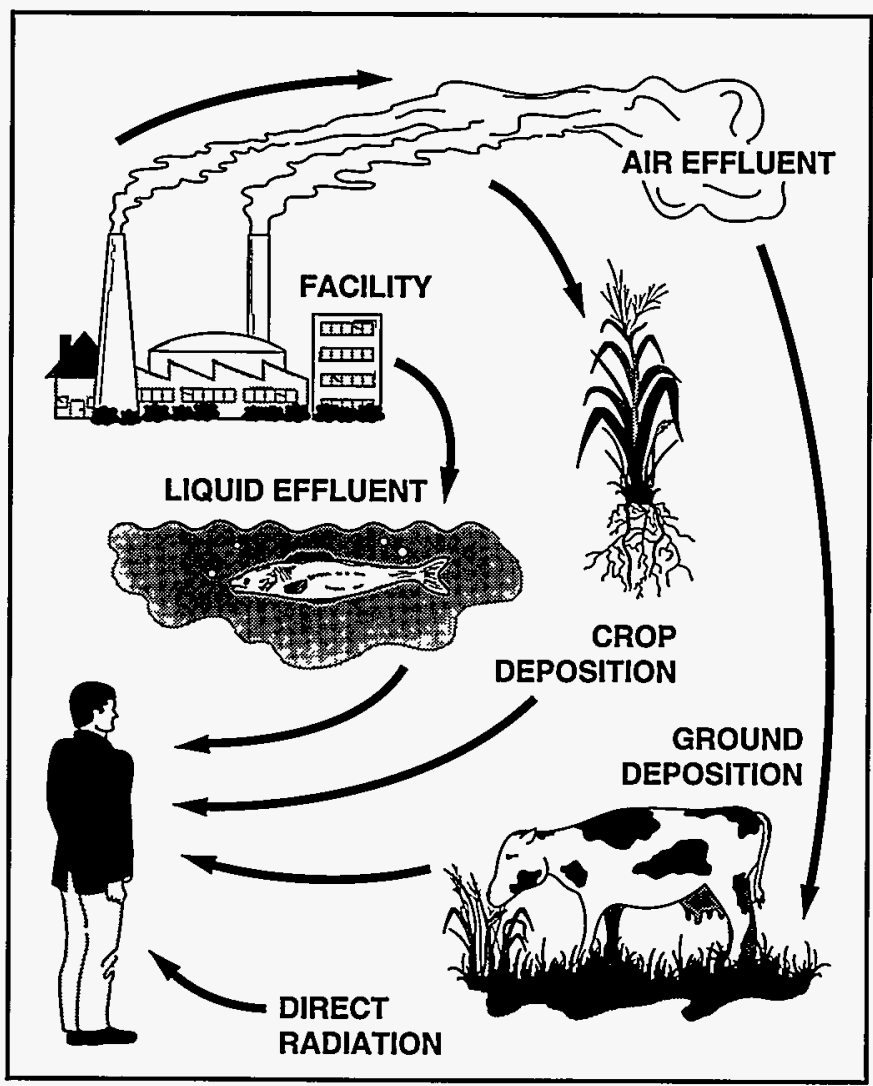

Figure 5. Possible radiation pathways. People can be exposed to radioactivity released from a nuclear facility in many ways. Radioactivity can leave the facility in airborne or liquid effluents and end up in the food people eat, the water they drink, or the air they breathe. be received at these locations, calculations are made assuming that a person stays in the area continuously.

Gamma levels measured around the site averaged 215 mrem per year on site and 214 mrem per year off site, near the reservation boundary. Figure 6 shows the average annual external gamma exposure on and around the Portsmouth site, for the state of Ohio, and for the United States as a whole. For a more general comparison refer to Figure 7, which shows the average annual doses from terrestrial gamma, cosmic, and total radiation for several states and the entire United States.

\section{WE EXAMINE THE AIR}

- Ambient air is the air that exits in the surroundings.

- Effluent air flows from a source out into the environment.

Both radiological and nonradiological air emissions from individual buildings and specific plant locations and in the surrounding communities are monitored. Air monitoring programs provide information to protect the health of plant workers and the general public and to demonstrate compliance with state and federal air quality requirements. Programs are upgraded periodically to meet revisions in state and federal requirements.

Although airborne radionuclides are the main source of any radiation dose received by the public from site operations, radionuclide emissions from the Portsmouth site had no significant impact on public health or the environment. Total radionuclide emissions from the Portsmouth site increased in 1994 because of increased technetium emissions from decontamination activities; however, emissions still remained well below the applicable USEPA standard and far below the levels listed as safe by national and international regulatory bodies such as the Occupational Safety and Health Administration. Radionuclides released to air in 1994 totaled 0.185 curies, $78 \%$ of which was technetium. Figure 8 shows the five-year trend for airborne radionuclides. 


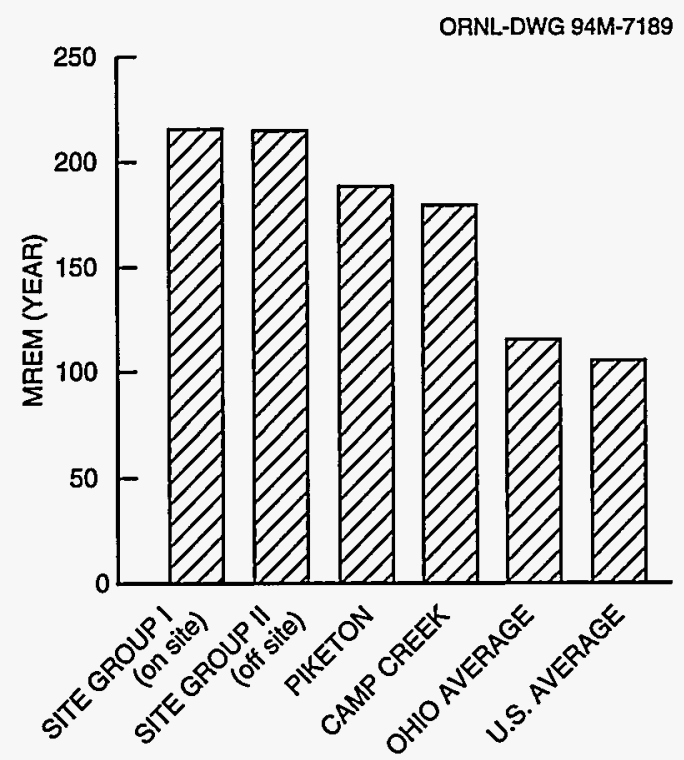

Figure 6. Average annual external gamma exposure on and around the Portsmouth site, for the state of Ohio, and for the United States as a whole.

Historically, uranium has accounted for 75 to almost $90 \%$ of the public dose from Portsmouth site emissions. Consequently, the emission control systems on the cascade are optimized to reduce uranium emissions first and technetium emissions second.

For the future, it is expected that mass emissions (kilograms) of uranium will remain about the same as levels seen from 1990 through 1994 and that the activity emissions (curies) of uranium should decrease after 1994 because of the absence of highly enriched uranium in the emissions.

In 1994, DOE achieved $100 \%$ compliance with all air permit limits for nonradiological releases.

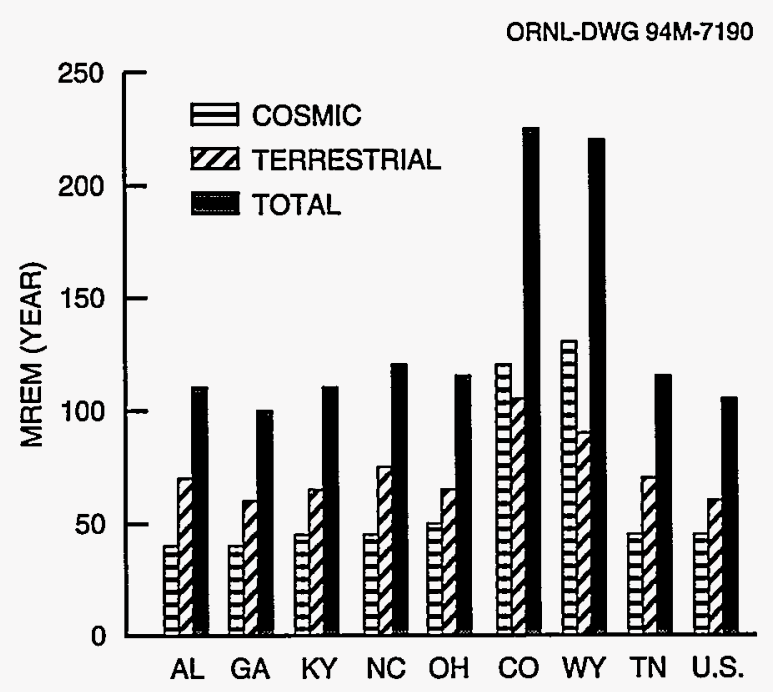

Figure 7. External cosmic, terrestrial, and total gamma exposure for several states and the United States as a whole.

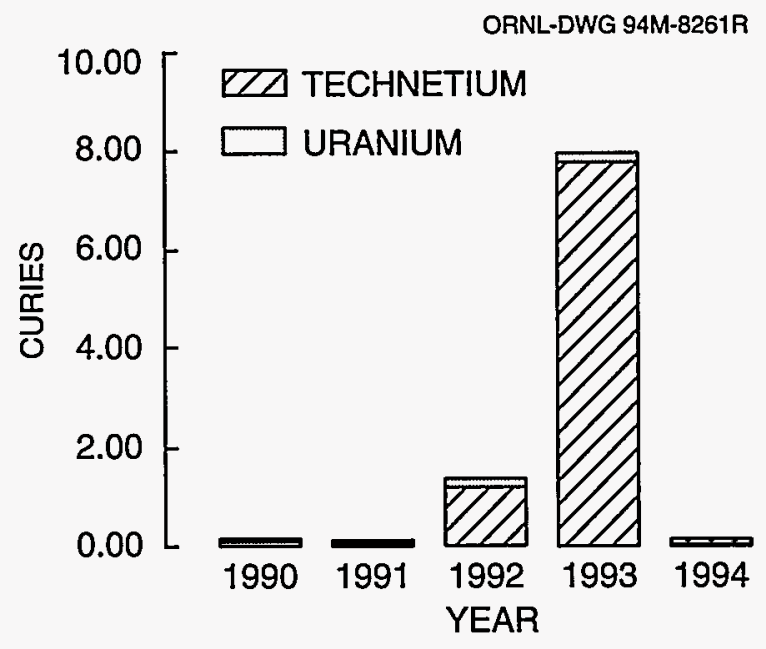

Figure 8. Airborne radionuclides discharged from the Portsmouth site, 1990-1994.

\section{WE EXAMINE GROUNDWATER}

By sampling the groundwater, we are able to evaluate the impact of Portsmouth site activities on local groundwater and to limit any activities that have an adverse effect on the groundwater. Major federal regulations specify actions to be followed in the groundwater monitoring program. More than $\mathbf{5 0 0}$ monitoring wells have been installed to track the flow of groundwater and to measure any contaminants present both on and off site. Groundwater monitoring extends to surface water that receives direct input from groundwater sources. Figure 9 shows the construction of a typical monitoring well used at the Portsmouth site. 


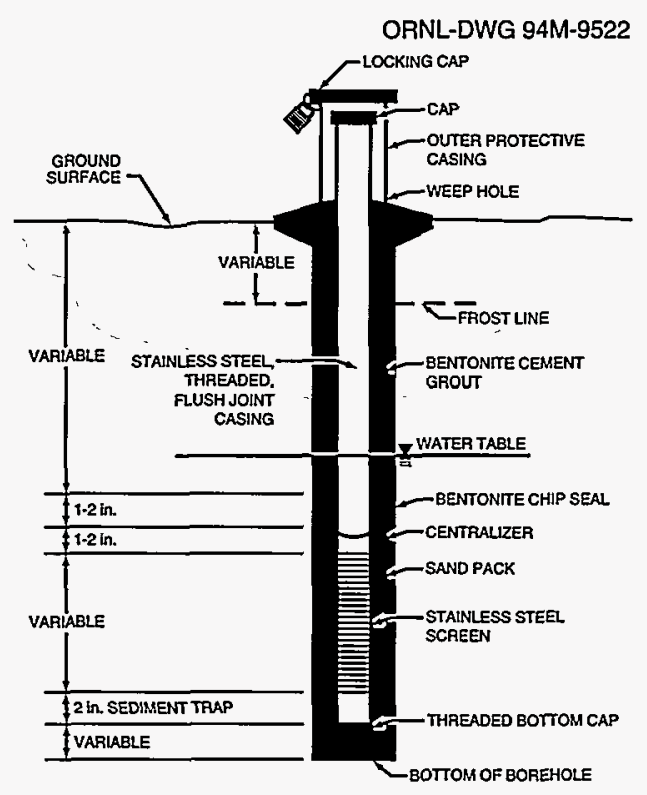

Figure 9. Typical monitoring well construction.

\section{WE EXAMINE SURFACE WATER}

Surface waters on the Portsmouth site are analyzed to ensure that water quality standards are met, to describe background water quality, to evaluate potential contaminant releases, and to comply with monitoring requirements of regulations, permits, and agreements.

Treated effluents either discharge to surface streams that pass through the reservation to the Scioto River or are piped directly to the Scioto River.

Radiological and nonradiological analyses of liquid effluent samples indicated that releases in 1994 were all well within applicable standards and posed no threat to human health or the environment. Figure 10 shows a five-year comparison of waterborne radionuclides released from the Portsmouth site.

\section{WE STUDY ECOLOGY}

In the summer and fall of 1993, DOE began preparing a baseline ecological risk assessment for the Portsmouth site.

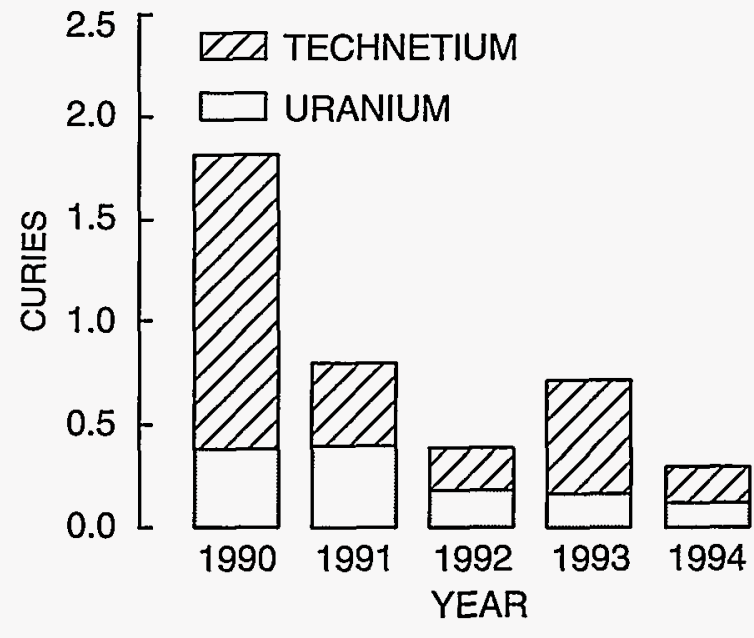

Figure 10. Waterborne radionuclides discharged from the Portsmouth site, 1990-1994.

Included as part of the risk assessment were a wetland survey, a threatened and endangered plant survey, a threatened and endangered animal survey, and a bat survey. The wetland survey identified a number of areas considered wetland or emergent wetland; these areas were delineated and mapped in April 1994. The threatened and endangered plant survey was completed in October 1994. Threatened and endangered species habitat survey results 
indicated the presence of several state-listed and possibly one federally listed threatened and endangered species within the Portsmouth reservation boundary. The bat survey, which was completed in September 1994, did not indicate the presence of the endangered Indiana Bat (Myotis sodalis).

In addition, a wildflower project was started to reduce maintenance costs and risks associated with mowing banks that are slumping or that are too steep to mow safely. An added benefit is that the wildflower areas will be aesthetically pleasing for site employees and visitors.

DOE is also developing a programmatic agreement with the State Historical Preservation Office. Structures of historic architectural importance, local archaeology, and cultural resources, such as the Mt. Gilead Cemetery, are covered under this agreement.

\section{COMPARISON OF DOSE LEVELS}

The dose received by a given individual can vary widely from year to year depending on numerous factors. The average individual in the United States receives a dose from natural exposure that is more than 200 times higher than he or she receives from nuclear industry operations (see Figure 11).
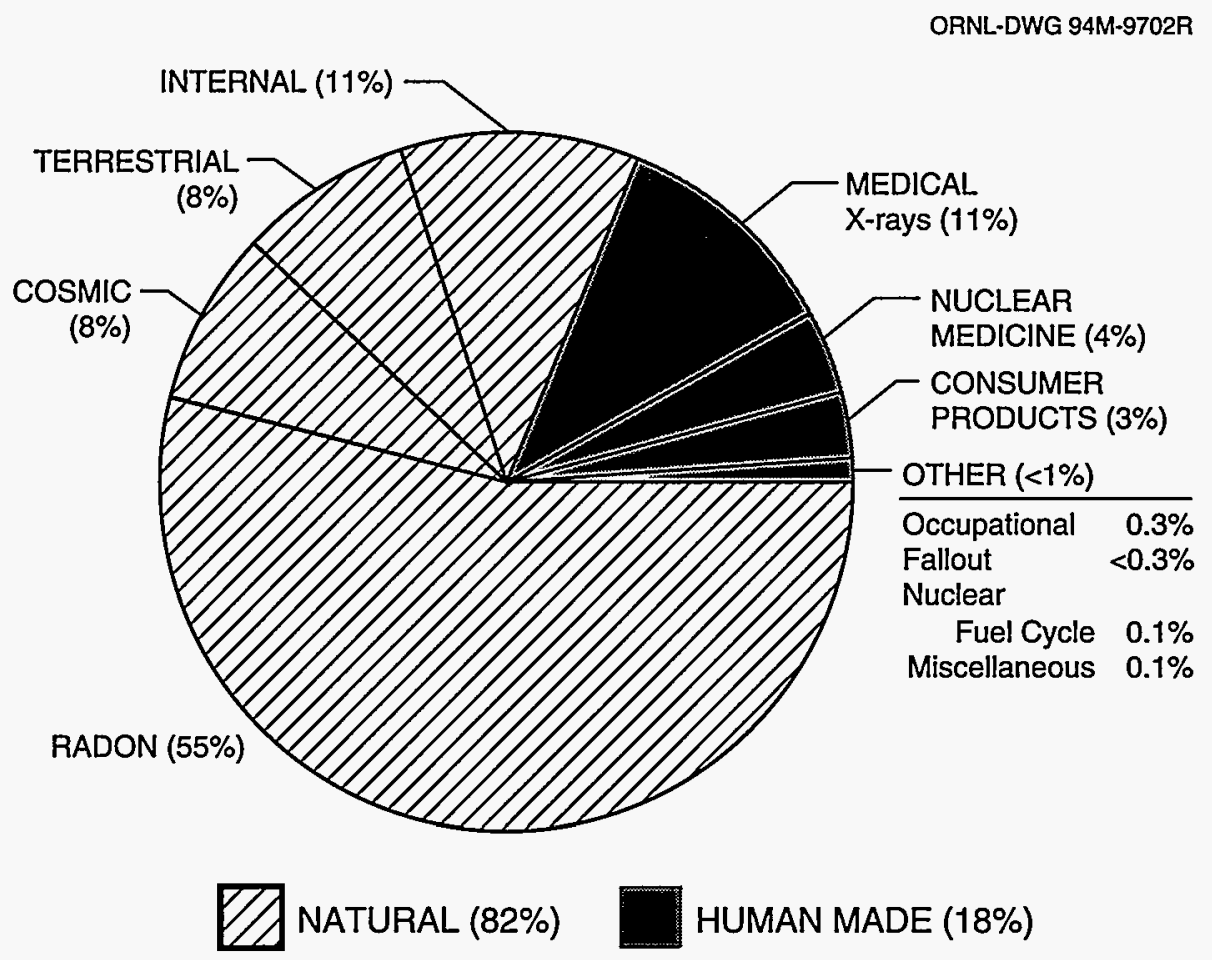

Figure 11. Sources of radiation. Radiation has always been present, and every person who has ever lived has been exposed. Although modern technology seems to have greatly increased the exposure rate, this is not necessarily the case. Exposure to human-made radiation varies greatly based on a given individual's product choices and medical treatments. In fact, exposure varies more based on where a person lives than on exposure to human-made sources. For example, the average individual in the United States receives 28 mrem per year from radioactive elements in the soil. However, the average dose from the soil in some areas of France is $\mathbf{3 5 0} \mathrm{mrem}$ per year. Figure redrawn with permission from the National Council on Radiation Protection and Measurements, Ionizing Radiation Exposure of the Population of the United States, NCRP Report No. 93, 1987. 
The average dose caused by background radiation also varies widely. In the United States, the average is about 300 mrem per year; however, some people in other parts of the world receive a dose more than four times this amount. For example, in some areas of Brazil the dose to inhabitants can be more than 2000 mrem per year from background radiation. These variations are caused by several factors, most notably the type and amount of radionuclides in the soil (see Figure 12).

This diversity in background radiation, not human-made radiation, is responsible for the large differences in the dose to average individuals. Because people living in areas with high levels of background radiation do so without proven harm, it is assumed by most in the scientific community that the extremely small variations in dose caused by Portsmouth site releases have inconsequential, if any, effect on humans. See Figure 13 for a comparison of various dose levels.

\section{SO ... WHAT DOES IT ALL MEAN?}

Everyone who works on the Portsmouth site remains committed to working safely, with regard to each other, the public, and the environment. This goal will be accomplished by keeping emissions as low as reasonably achievable, enhancing the strict safety controls that are already in place and by using state-of-the-art technology to complete environmental remediation projects in the most cost-effective and efficient manner possible.

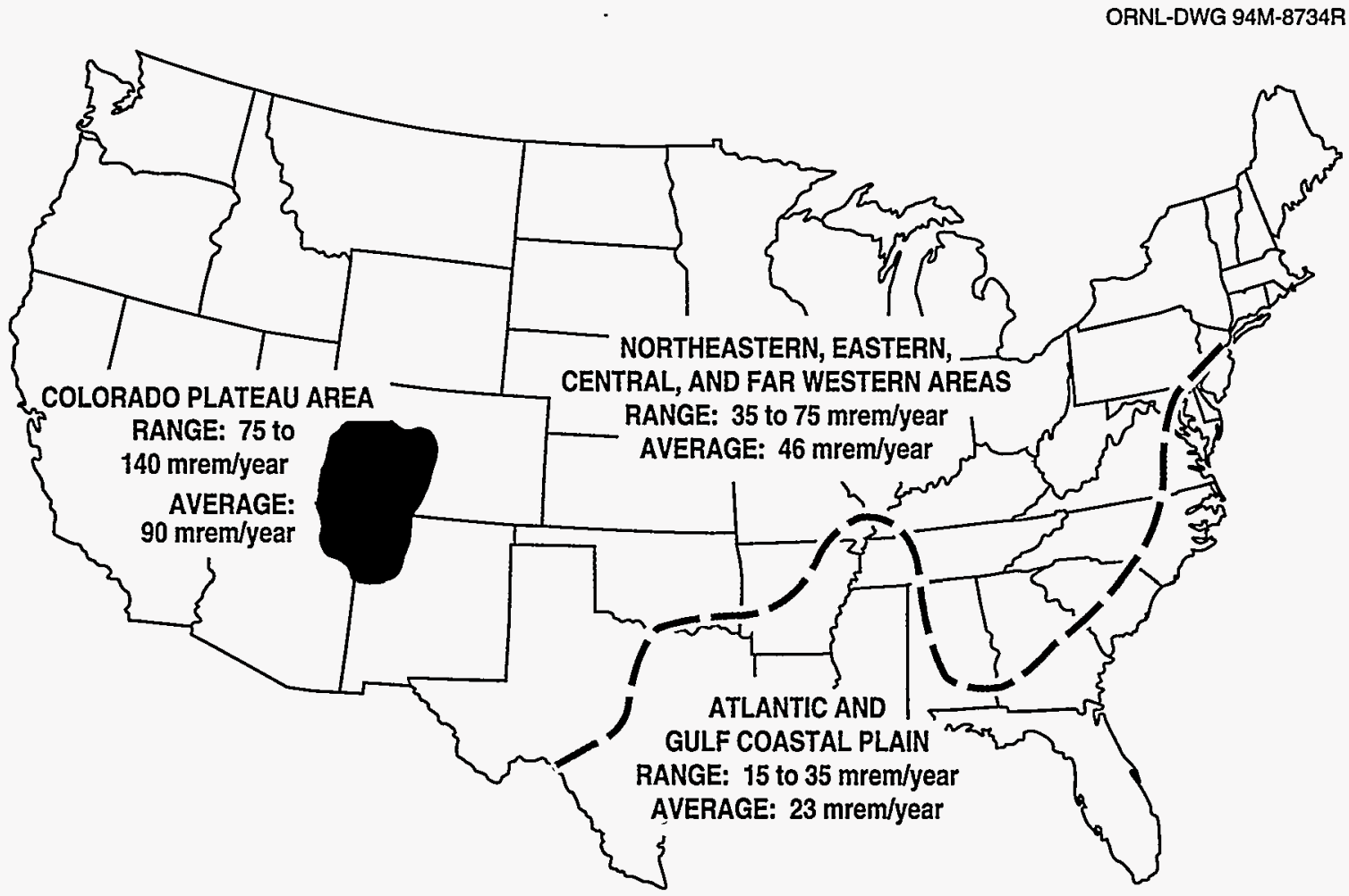

Figure 12. Average dose from terrestrial radiation in the United States. Large deposits of uranium and thorium ores in the southwest are responsible for the higher-than-average dose in the Colorado Plateau area. Figure redrawn with permission from the Subcommittee on Risks of Low-Level lonizing Radiation, Low-Level Radiation Effects: A Fact Book, The Society of Nuclear Medicine, Inc., 1985. 
Annual Environmental Report Summary

ORNL-DWG 95M-8125

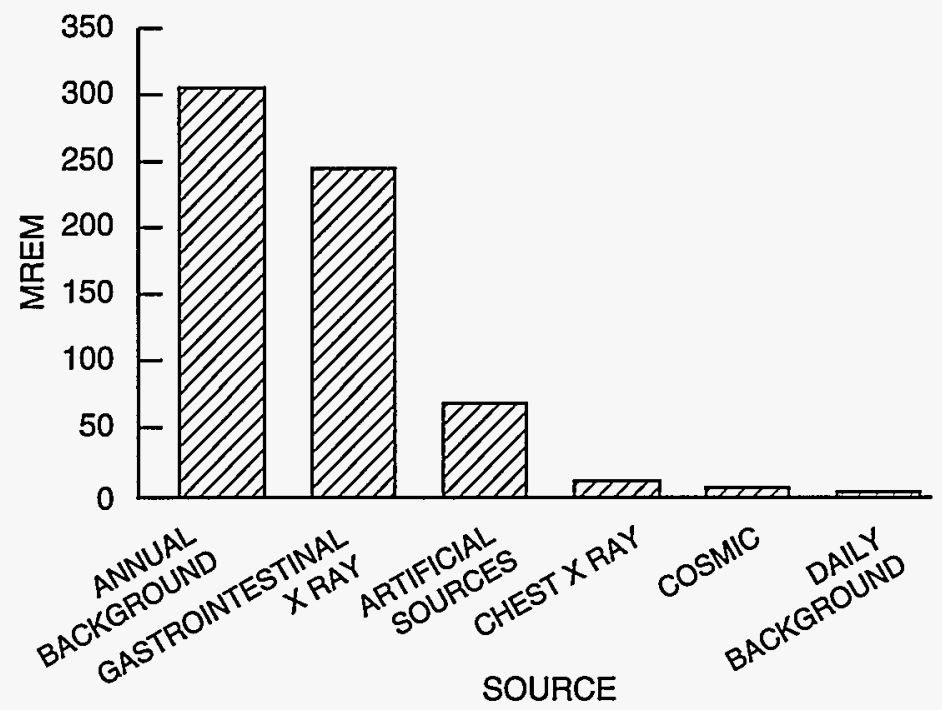

Figure 13. Comparison of dose from various common radiation sources.

13 